\title{
Optimasi Penempatan dan Kapasitas Bank Capacitor Untuk Mereduksi Rugi-Rugi Daya Menggunakan Kombinasi Metode Loss Sensitivity Factors dan Particle Swarm Optimization (PSO)
}

\author{
Fikri Adi Anggara ${ }^{1}$, Osea Zebua ${ }^{2}$, Khairuddin Hasan $^{3}$ \\ Jurusan Teknik Elektro Universitas Lampung, Bandar Lampung \\ J1. Prof. Sumantri Brojonegoro No.1 Bandar Lampung 35145 \\ ${ }^{1}$ fikriadianggara@gmail.com \\ ${ }^{2}$ osea.zebua@eng.unila.ac.id \\ ${ }^{3} \mathrm{khairudinhs}$ eng. unila.ac.id
}

Intisari - Sistem distribusi yang memiliki saluran panjang biasanya memiliki masalah rugi-rugi daya dan votage drop. Masalah ini dapat diatasi dengan cara menempatkan capacitor bank pada sistem distribusi. Masalah utama dalam penempatan capacitor bank adalah menentukan lokasi dan kapasitas yang optimal. Penelitian ini menggunakan metode Loss Sensitivity Factors (LSF) untuk menentukan kandidat bus yang akan dipilih sebagai lokasi penempatan capacitor bank dan metode algoritma Particle Swarm Optimization digunakan untuk mencari kapasitas optimal capacitor bank yang dipasang. Simulasi dilakukan dengan menggunakan perangkat lunak MATLAB. Studi kasus yang digunakan adalah kasus uji IEEE 10 bus dan penyulang Pakis di gardu induk Menggala. Hasil simulasi menunjukkan bahwa kombinasi kedua metode dapat menentukan lokasi penempatan dan kapasitas optimal capacitor bank dengan reduksi rugi-rugi daya yang minimum untuk kedua studi kasus.

Kata kunci - Rugi-Rugi Daya, Capacitor Bank, Loss Sensitivity Factors, Algoritma Particle Swarm Optimization.

Abstract - Distribution systems that have long lines usually have problems with power losses and votage drop. This problem can be overcome by placing a bank capacitor in the distribution system. The main problem in the placement of bank capacitors is determining the optimal location and capacity. This study uses the Loss Sensitivity Factors (LSF) method to determine the candidate bus that will be selected as the location of the placement of bank capacitors and the Particle Swarm Optimization algorithm method is used to find the optimal capacity of the installed bank capacitor. Simulation is done using MATLAB software. The case studies used were the IEEE 10 bus and Pakter feeder test cases at the Menggala substation. The simulation results show that the combination of the two methods can determine the placement location and optimal capacitor capacity of the bank by reducing the minimum power losses for the two case studies.

Keywords- Active power losses, Capacitor Bank, Loss Sensitivity Factors, Particle Swarm Optimization Algorithm.

\section{PENDAHULUAN}

Beban listrik yang semakin meningkat pada sistem distribusi mengakibatkan semakin meningkatnya rugi-rugi daya pada saluran dan menurunkan profil tegangan pada setiap bus. Pada kasus dimana beban-beban listrik terletak jauh dari sumber daya atau gardu induk seperti pada sistem distribusi di daerah pedesaan, rugi-rugi daya semakin besar dengan semakin panjangnya saluran.

Salah satu cara untuk mengurangi rugi-rugi daya saluran sekaligus memperbaiki profil tegangan adalah dengan menempatkan kapasitor-kapasitor paralel pada sistem distribusi [1],[2]. Namun penempatan kapasitor dengan kapasitas yang tidak optimal dapat mengakibatkan profil tegangan yang berbeda-beda pada setiap bus dan bahkan dapat meningkatkan tegangan pada suatu bus sementara pada bus lain tegangan dapat menurun. Kenaikan nilai tegangan yang melebihi batas operasinya dapat menyebabkan kerusakan pada beban-beban listrik. 
Profil beban harian menjadi pertimbangan untuk penempatan kapasitor paralel. Beban listrik biasanya rendah pada pagi hari dan meningkat pada sore dan malam hari.

Berbagai penelitian yang terdahulu telah mencari lokasi dan kapasitas bank kapasitor pada jaringan distribusi dengan fungsi objektif yang berbeda-beda, yaitu dengan metode deterministik yang terdiri dari Linear Progamming [3], Non-Linear Progamming [4], Mixed Integer Progamming [5], serta metode meta-heuristik terdiri dari Genetic Algorithm [6], Simulated Annealing [7], Fuzzy Logic [8], Tabu Search [9], dan lainlain.

Algoritma PSO telah diuji dan sangat efektif untuk digunakan dalam penyelesaian penentuan nilai capacitor bank pada sistem distribusi [10].

Makalah ini menyajikan optimasi kapasitas dan penempatan bank kapasitor untuk meminimisasi rugi-rugi sekaligus memperbaiki profil tegangan dengan menggunakan metode Loss Sensitivity Factors (LSF) dan Particle Swarm Optimization (PSO). Studi kasus yang digunakan adalah kasus uji IEEE 10 bus dan Penyulang Pakis di Gardu Induk Menggala Lampung.

\section{TINJAUAN PUSTAKA}

\section{A. Rugi-rugi Daya Pada Sistem Distribusi}

Rugi-rugi daya pada sistem distribusi biasanya merupakan rugi-rugi pada saluran dan rugi-rugi pada transformator. Rugi-rugi daya pada saluran terdiri dari rugi-rugi daya aktif dan rugi-rugi daya reaktif. Pada sistem distribusi radial dengan $n$ bus, rugi-rugi daya aktif total dinyatakan dengan:

$$
P_{\text {totalloss }}=\sum_{i=1}^{n-1} P_{\text {loss }(i, i+1)}
$$

dimana $P_{l o s s(i, i+1)}$ adalah rugi-rugi daya aktif pada saluran yang menghubungkan bus $i$ dan bus $i+1$, yang dinyatakan dengan:

$$
P_{\text {loss }(i, i+1)}=I_{i}^{2} R_{i}
$$

\section{B. Faktor Sensitivitas Rugi-rugi}

Faktor sensitivitas rugi-rugi atau loss sensitivity factors (LSF) dapat digunakan untuk memprediksi bus-bus yang menjadi kandidat untuk penempatan kapasitor [10]. Rugi-rugi daya pada saluran $k$ yang menghubungkan bus $p$ dan bus $q$ dengan impedansi $R[k]+j X[k]$ dan total daya efektif yang disuplai di luar bus $q$, $P_{e f f}+j Q_{e f f}$ adalah:

$$
P_{\text {loss }}[k]=\frac{\left(P_{\text {eff }}^{2}[q]+Q_{\text {eff }}^{2}[q] R[k]\right)}{V[q]^{2}}
$$

dan

$$
Q_{\text {loss }}[k]=\frac{\left(P_{\text {eff }}^{2}[q]+Q_{\text {eff }}^{2}[q] X[k]\right)}{V[q]^{2}}
$$

Faktor sensitivitas rugi-rugi dihitung dengan persamaan:

$$
\begin{aligned}
& \frac{\partial P_{\text {lineloss }}}{\partial Q_{\text {eff }}}=\frac{\left(2 Q_{\text {eff }}^{2}[q] R[k]\right)}{V[q]^{2}} \\
& \frac{\partial Q_{\text {lineloss }}}{\partial Q_{\text {eff }}}=\frac{\left(2 Q_{\text {eff }}^{2}[q] X[k]\right)}{V[q]^{2}}
\end{aligned}
$$

Kandidat bus untuk penempatan bank kapasitor dipilih dengan memperhatikan nilai LSF untuk rugi-rugi daya aktif pada persamaan 5 dan norm tegangan bus $i$ terhadap tegangan minimum, yakni:

$$
\operatorname{norm}(i)=\frac{V_{i}}{V_{\min }}
$$

Bila bus dengan nilai norm(i) kurang dari 1,01 dan nilai LSF daya aktif yang terbesar, maka bus tersebut dapat dipilih menjadi kandidat untuk penempatan bank kapasitor.

\section{Particle Swarm Optimization}

Particle Swarm Optimization (PSO) adalah suatu metode optimisasi berbasis kecerdasan kelompok atau populasi. Metode optimisasi ini terinspirasi oleh tingkah laku sosial dari sekawanan burung yang terbang 
bersama-sama untuk mencari makan. Setiap individu atau partikel mempunyai kecerdasan atau pengetahuan sendiri dalam memburu makanan [11].

Setiap partikel terletak pada posisi awal secara acak dalam ruang multidimensi dan mempunyai karakteristik yakni posisi (position) dan kecepatan (velocity). Setiap partikel bergerak dalam ruang pencarian (search space) dan mengingat posisi terbaik (Pbest) yang pernah dilalui atau ditemukan terhadap sumber makanan atau nilai fungsi objektif (fitness). Nilai fungsi objektif yang terbaik suatu partikel dari keseluruhan kawanan menjadi penyelesaian terbaik dari fungsi objektif (Gbest).

Setelah mendapatkan dua penyelesaian terbaik, Pbest dan Gbest, partikel akan memperbaharui kecepatan dengan persamaan:

$$
\begin{aligned}
v_{i}^{(t+1)}= & k w v_{i}^{(t)}+c_{1} r_{1}\left(\text { Pbest }^{i}-x_{i}^{(t)}\right) \\
& +c_{2} r_{2}\left(\text { Gbest }^{i}-x_{i}^{(t)}\right)
\end{aligned}
$$

dimana

$$
k=\frac{2}{\left|2-\varphi-\sqrt{\varphi^{2}-4 \varphi}\right|}
$$

dengan nilai $\varphi=c_{1}+c_{2}$ dan $\varphi>4$ dan update posisi dihitung dengan menggunakan persamaan berikut:

$$
x_{i}^{(t+1)}=x_{i}^{(t)}+v_{i}^{(t+1)}
$$

dimana: $v_{i}^{(t+1)}$ adalah kecepatan partikel $i$ pada iterasi ke-(t+1), $x_{i}^{(t+1)}$ adalah posisi partikel $i$ pada iterasi ke-(t+1), $v_{i}^{(t)}$ dan $x_{i}^{(t)}$ masing-masing adalah kecepatan dan posisi partikel pada iterasi ke- $t, c_{1}$ dan $c_{2}$ adalah konstanta positif (learning factor), w adalah bobot inersia, Pbest ${ }^{i}$ dan Gbest $^{i}$ masing-masing adalah penyelesaian terbaik dari partikel dan kawanan ke- $i, r_{1}$ dan $r_{2}$ adalah dua bilangan yang terletak dalam rentang $[0,1]$.
Bobot inersia $w$ yang digunakan untuk meredam kecepatan partikel untuk mencari titik opimal yang akurat dan efisien dituliskan dengan persamaan:

$$
w^{(t)}=w_{\text {max }}-\left(\frac{w_{\text {max }}-w_{\text {min }}}{i t e r_{\max }}\right)
$$

dimana $w^{(t)}$ adalah bobot inersia pada iterasi ke- $t, w_{\max }$ dan $w_{\text {min }}$ adalah batas atas dan batas bawah dari bobot inersia, iter dan iter $_{\max }$ masing-masing adalah jumlah iterasi dan iterasi maksimum

\section{Fungsi Objektif}

Penempatan kapasitor pada sistem distribusi harus memenuhi fungsi objektif yakni meminimisasi total biaya sistem yakni total biaya rugi-rugi daya ditambah dengan biaya instalasi pemasangan bank kapasitor, yang diberikan dengan persamaan:

$$
\begin{aligned}
\min F & =K_{p c} P_{\text {Tloss }}+K_{c i} Q_{c i}^{\text {total }} \\
& =K_{p c} \sum_{i=1}^{n b-1} P_{\text {loss }, i}+K_{c} \sum_{i=1}^{N_{c}} Q_{c i}
\end{aligned}
$$

Fungsi objektif diminimisasi dengan memenuhi beberapa batasan pertidaksamaan (inequality constraint), antara lain:

a. Batasan magnitude tegangan untuk beberapa bus:

$$
V_{\min } \leq V_{i} \leq V_{\max }
$$

Nilai tegangan minimum dan maksimum masing-masing adalah $0,95 \mathrm{pu}$ dan 1,05 pu. Nilai $l$ adalah 10.

b. Batasan jumlah bank kapasitor yang dipasang:

$$
N_{c} \leq N_{c}^{\max }
$$

c. Batasan kapasitas bank capacitor:

$$
Q_{c i} \leq Q_{c i} \leq Q_{c i}^{\max }
$$

d. Batasan total injeksi daya reaktif: 


$$
Q_{c i}^{\text {total }} \leq Q_{L}^{\max }
$$

dimana $F$ adalah biaya total sistem (\$/tahun), $K_{p c}$ adalah konstanta rugi-rugi daya aktif $(0,06 \$ / \mathrm{kWh}), \quad K_{q c}$ adalah konstanta biaya bank kapasitor ( $3 \$ / \mathrm{kVAR}), N_{c}$ adalah jumlah bank kapasitor yang dipasang, $Q_{c i}^{\text {total }}$ adalah daya reaktif total yang diinjeksikan bank kapasitor $(\mathrm{kVAR})$ dan $Q_{L}^{\text {total }}$ adalah daya reaktif beban total (kVAR).

Kapasitas bank kapasitor yang dipasang merupakan kelipatan dari kapasitas terkecil, $Q_{c}^{0}$ dan ditulis dengan persamaan:

$$
Q_{c i}^{\max }=L \times Q_{c}^{0}
$$

dimana $L$ adalah suatu bilangan integer dan $Q_{c}^{0}$ merupakan kapasitas terkecil dari standar bank kapasitor yang besarnya 50 kVAR.

\section{METODE PENELITIAN}

\section{A. Pemodelan Sistem Distribusi}

Sistem distribusi penyulang Pakis dimodelkan dengan model bus dan model saluran. Pemodelan sistem distribusi dilakukan untuk perhitungan aliran daya menggunakan perangkat lunak MATPOWER. Model bus terdiri dari data-data nomor bus, tipe bus, magnitude tegangan dan sudut tegangan, beban daya aktif dan daya reaktif setiap bus. Model saluran meliputi data-data nomor saluran yang menghubungkan satu bus ke bus lainnya, dan nilai resistansi dan reaktansi saluran. Jumlah bus dan saluran di penyulang Pakis masing-masing adalah 263 bus dan 262 saluran.

\section{B. Optimasi Penempatan Dan Kapasitas Bank Kapasitor}

Optimasi penempatan dan rating bank kapasitor dilakukan dengan mencari lokasi optimal penempatan bank kapasitor dengan menggunakan metode LSF dan kemudian mencari kapasitas optimal bank kapasitor menggunakan metode PSO. Jumlah bus dimana bank kapasitor yang akan ditempatkan ditentukan sebanyak 5 bus.
Prosedur optimasi penempatan dan rating bank kapasitor dijelaskan sebagai berikut:

1. Masukkan data-data untuk model bus dan model saluran.

2. Hitung aliran daya sistem distribusi penyulang Pakis.

3. Hitung nilai LSF dan norm tegangan untuk setiap bus menggunakan persamaan 7 dan pilih 5 bus sebagai kandidat bus.

4. Hitung kapasitas optimal bank kapasitor untuk berbagai level beban yang meminimalkan fungsi objektif dengan menggunakan metode PSO. Pilih kapasitas yang paling besar dari kapasitas bank kapasitor yang diperoleh pada setiap level beban.

\section{HASIL DAN PEMBAHASAN}

Simulasi penentuan lokasi dan kapasitas optimal dari capacitor bank dilakukan dengan menggunakan dua studi kasus, yakni kasus IEEE 10 Bus Radial Distribution Test System dengan Fixed Capacitor Bank dan Penyulang Pakis di gardu induk Menggala dengan menggunakan Switched Capacitor Bank.

\section{A. Kasus Uji IEEE 10 Bus dengan Fixed Capacitor Bank}

Kasus uji ini memiliki tegangan operasi 23 $\mathrm{kV}$ dan basis daya sebesar 100 MVA. Beban terdiri dari beban daya aktif total sebesar 12,368 MW dan beban daya reaktif total sebesar 4,186 MVAR. Diagram satu garis dari kasus uji IEEE 10 bus ditunjukkan pada gambar 1 .

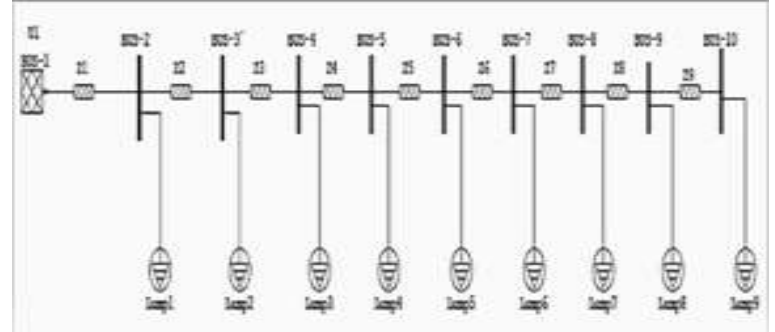

Gbr 1. Diagram Satu Garis Kasus Uji IEEE 10 Bus

Data beban dan saluran dari kasus uji IEEE 10 bus ditunjukkan pada tabel 1 . 
Tabel 1. Data Beban dan Saluran Kasus Uji IEEE 10 Bus

\begin{tabular}{|c|c|c|c|c|c|}
\hline $\begin{array}{c}\text { Dari } \\
\text { bus }\end{array}$ & $\begin{array}{c}\text { Ke } \\
\text { Bus }\end{array}$ & $\begin{array}{c}\mathrm{P} \\
(\mathrm{kW})\end{array}$ & $\begin{array}{c}\mathrm{Q} \\
(\mathrm{kVAR})\end{array}$ & $\begin{array}{c}\mathrm{R} \\
(\mathrm{ohm})\end{array}$ & $\begin{array}{c}\mathrm{X} \\
(\mathrm{ohm})\end{array}$ \\
\hline 1 & 2 & 1840 & 460 & 0,1233 & 0,4127 \\
\hline 2 & 3 & 980 & 340 & 0,014 & 0,6057 \\
\hline 3 & 4 & 1790 & 446 & 0,7463 & 1,205 \\
\hline 4 & 5 & 1598 & 1840 & 0,6984 & 0,6084 \\
\hline 5 & 6 & 1610 & 600 & 1,9831 & 1,7276 \\
\hline 6 & 7 & 780 & 110 & 0,9053 & 0,7886 \\
\hline 7 & 8 & 1150 & 60 & 2,0552 & 1,164 \\
\hline 8 & 9 & 980 & 130 & 4,7943 & 2,716 \\
\hline 9 & 10 & 1640 & 200 & 5,3434 & 3,0264 \\
\hline
\end{tabular}

Pengujian dengan kasus uji IEEE 10 bus dilakukan dengan menggunakan program PSO dan perangkat lunak komersial ETAP versi 12.6.0.

Hasil simulasi untuk kasus uji IEEE 10 bus ditunjukkan pada gambar 2 .

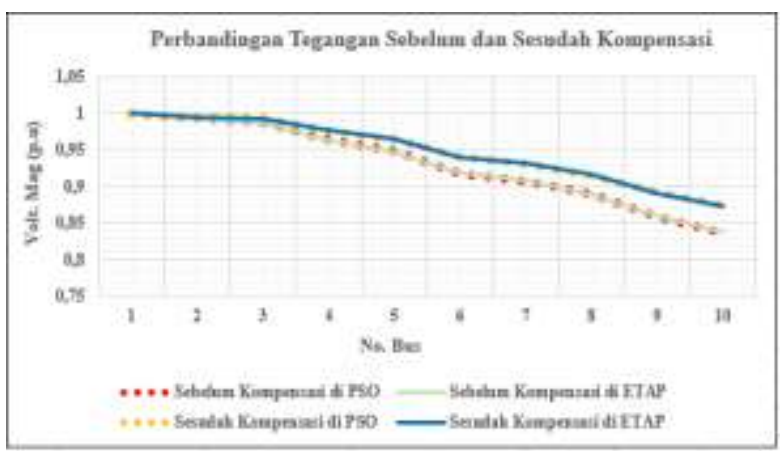

Gbr. 2. Perbandingan Profil Tegangan Sebelum dan Sesudah Kompensasi dengan menggunakan PSO dan ETAP

Hasil simulasi menunjukkan kesesuaian pada hasil profil tegangan sebelum dan sesudah ditempatkan bank kapasitor baik dengan menggunakan PSO maupun dengan menggunakan ETAP. Tegangan terendah sebelum penempatan kapasitor berada pada bus 10 dengan nilai tegangan sebesar 0,8375 pu atau 19,26 kV, kemudian tegangan terendah ini naik menjadi $0,8734 \mathrm{pu}$ atau 20,089 $\mathrm{kV}$ pada bus yang sama setelah penempatan bank kapasitor.

Hasil optimasi kapasitas bank kapasitor untuk kasus uji IEEE 10 bus ditunjukkan pada tabel 2.
Tabel 2. Hasil Optimasi Bank Kapasitor Pada Kasus Uji IEEE 10 Bus

\begin{tabular}{|c|c|c|}
\hline No. Bus & $\begin{array}{c}\text { Kapasitas Bank } \\
\text { Kapasitor }\end{array}$ & $\begin{array}{c}\text { Jumlah } \\
\text { Unit }\end{array}$ \\
\hline 5 & 1050 & 21 \\
\hline 6 & 1150 & 23 \\
\hline 9 & 400 & 8 \\
\hline 10 & 600 & 12 \\
\hline Total & 3200 & 64 \\
\hline
\end{tabular}

Penempatan bank kapasitor pada keempat bus dengan total injeksi daya reaktif sebesar 3200 kVAR, mampu mereduksi rugi-rugi daya aktif dari kondisi sebelum optimasi yaitu sebesar 0,7837 MW menjadi 0,6991 MW setelah optimasi, artinya terjadi pengurangan rugi-rugi daya aktif sebesar $10,802 \%$, seperti yang ditunjukkan pada gambar 3 di bawah ini. Perbandingan rugirugi daya reaktif sebelum dan sesudah optimasi penempatan bank kapasitor ditunjukkan pada gambar 4 .

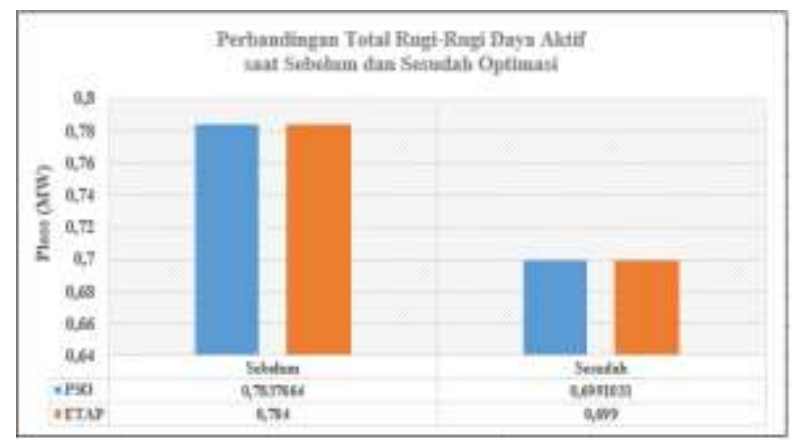

Gbr. 3. Perbandingan Rugi-rugi Daya Aktif Total Sebelum dan Sesudah Penempatan Bank Kapasitor

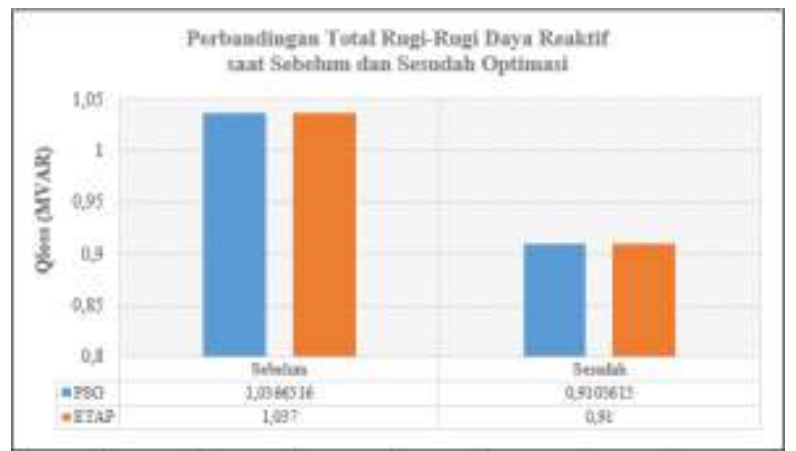

Gbr. 4. Perbandingan Rugi-rugi Daya Reaktif Total Sebelum dan Sesudah Penempatan Bank Kapasitor 
Hasil simulasi secara keseluruhan dengan PSO juga dibandingkan dengan hasil simulasi dari beberapa metode lain, seperti ditunjukkan pada tabel 3.

Tabel 3. Perbandingan Hasil Optimasi Beberapa Algoritma Untuk Kasus Uji IEEE 10 Bus

\begin{tabular}{|l|c|c|c|c|}
\hline & $\begin{array}{c}\text { Sebelum } \\
\text { Kompensasi }\end{array}$ & $\begin{array}{c}\text { Fuzzy } \\
\text { Reasoning } \\
{[12]}\end{array}$ & $\begin{array}{c}\text { Modified } \\
\text { Artificial } \\
\text { Bee } \\
\text { Colony } \\
{[13]}\end{array}$ & $\begin{array}{c}\text { Metode } \\
\text { PSO yang } \\
\text { digunakan }\end{array}$ \\
\hline $\begin{array}{l}\text { Rugi-rugi } \\
\text { daya aktif } \\
\text { total (kW) }\end{array}$ & 783,77 & 704,883 & 693,93 & $\mathbf{6 9 9 , 1 0 3}$ \\
\hline $\begin{array}{l}\text { Reduksi } \\
\text { rugi-rugi (\%) }\end{array}$ & - & 10,065 & 11,46 & $\mathbf{1 0 , 8 0 2}$ \\
\hline $\begin{array}{l}\text { Lokasi dan } \\
\text { Kapasitas } \\
\text { Optimal } \\
\text { (kVAR) }\end{array}$ & - & $\begin{array}{c}(4,1050) ; \\
(6,1050) ; \\
(10,900) ;\end{array}$ & $\begin{array}{c}(5,1200) ; \\
(6,1200) ; \\
(10,450) ;\end{array}$ & $\begin{array}{c}\mathbf{( 5 , 1 1 5 0 ) ;} \\
(\mathbf{6 , 4 0 5 0} ;\end{array}$ \\
\hline $\begin{array}{l}\text { Total } \\
\text { (kVAR) }\end{array}$ & $\mathbf{1 0 , 6 0 0 ) ;} ;$ \\
\hline Vmax (p.u) & 1,0 & 4950 & 3000 & $\mathbf{3 2 0 0}$ \\
\hline Vmin (p.u) & 0,8375 & 0,902 & 0,8715 & $\mathbf{0 , 8 7 3 4}$ \\
\hline $\begin{array}{l}\text { Biaya Energi } \\
\text { Tahunan } \\
\text { Total (\$) }\end{array}$ & 411947,6 & 370489,13 & 364729,6 & $\mathbf{3 6 4 7 2 8 , 9 4}$ \\
\hline $\begin{array}{l}\text { Biaya Bank } \\
\text { kapasitor }(\$)\end{array}$ & - & 14850 & 9000 & 10950 \\
\hline $\begin{array}{l}\text { Penghematan } \\
\text { Biaya } \\
\text { Tahunan }(\$)\end{array}$ & - & 26608,47 & 38218 & $\mathbf{3 6 2 8 6 , 6 6 5}$ \\
\hline
\end{tabular}

Hasil optimasi menunjukkan bahwa metode PSO jauh lebih efisien dalam segi kapasitas maupun penurunan rugi-rugi daya aktif dibandingkan dengan metode fuzzy reasoning, sedangkan untuk peningkatan profil tegangan metode PSO lebih unggul dibandingkan metode Modified $A B C$.

\section{B. Penyulang Pakis 263 Bus dengan Switched Capacitor Bank}

Penyulang Pakis merupakan suatu penyulang distribusi $20 \mathrm{kV}$ dari gardu induk Menggala. Penyulang ini dimodelkan dengan 262 bus, dimana 241 bus di antaranya adalah bus beban. Panjang saluran pada Penyulang Pakis adalah $266 \mathrm{kms}$, hal ini mengakibatkan tingginya rugi-rugi daya dan jatuh tegangan di sepanjang saluran. Diagram satu garis dari penyulang Pakis ditunjukkan pada gambar 5.

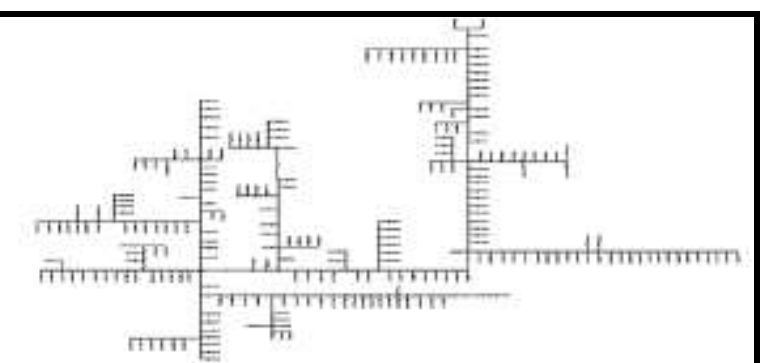

Gbr. 5. Diagram Satu Garis Penyulang Pakis

Beban total pada penyulang Pakis terdiri dari beban daya aktif sebesar 7,5981 MW dan beban daya reaktif sebesar 4,7419 MVAR pada kondisi pagi hari, 9,822 MW dan 6,1298 MVAR pada kondisi siang hari, 14,6403 MW dan 9,1369 MVAR pada malam hari. Kurva beban harian ditunjukkan pada gambar 6. Data lama beban ditunjukkan pada tabel 4 .

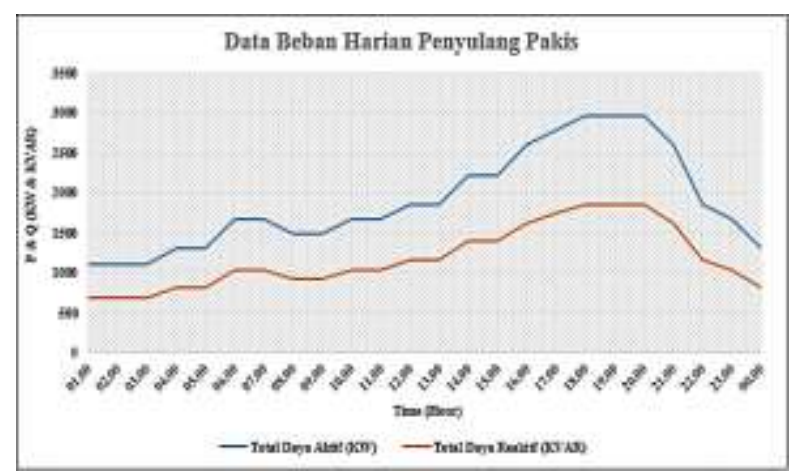

Gbr.6. Kurva Beban Harian Penyulang Pakis

Tabel. 4. Data Lama Beban Penyulang Pakis

\begin{tabular}{|c|c|c|c|c|}
\hline $\begin{array}{c}\text { Kondisi } \\
\text { Bebaai }\end{array}$ & $\begin{array}{c}\text { Daya Aktif } \\
\text { (kW) }\end{array}$ & $\begin{array}{c}\text { Daya Reaktif } \\
\text { (kVAR) }\end{array}$ & $\begin{array}{l}\text { Presentase } \\
\text { Pembebanal }\end{array}$ & $\begin{array}{c}\text { Load duration } \\
\text { (Hour) }\end{array}$ \\
\hline \multirow{3}{*}{ Pagi } & 1111,929 & 693,9465 & $30 \%$ & 3 \\
\hline & 1297,2505 & 809,60425 & $35 \%$ & 3 \\
\hline & 1482,572 & 925.262 & $40 \%$ & 2 \\
\hline \multirow{2}{*}{ Slang } & 1067,8935 & 1040,91975 & $45 \%$ & 5 \\
\hline & 1853,215 & 1156,5775 & $50 \%$ & 3 \\
\hline \multirow{2}{*}{ Sore } & 2223,858 & 1357,893 & $60 \%$ & 2 \\
\hline & 2595,501 & 1619,2085 & $70 \%$ & 2 \\
\hline \multirow{2}{*}{ Malam } & 2779,8225 & 1734,86625 & $75 \%$ & 1 \\
\hline & 2965,144 & 1850,524 & $80 \%$ & 3 \\
\hline \multicolumn{4}{|c|}{ Total } & 24 \\
\hline
\end{tabular}

Analisa untuk kondisi pembebanan penyulang Pakis didapatkan dari transformator distribusi yang terpasang pada masing-masing gardu distribusi. 


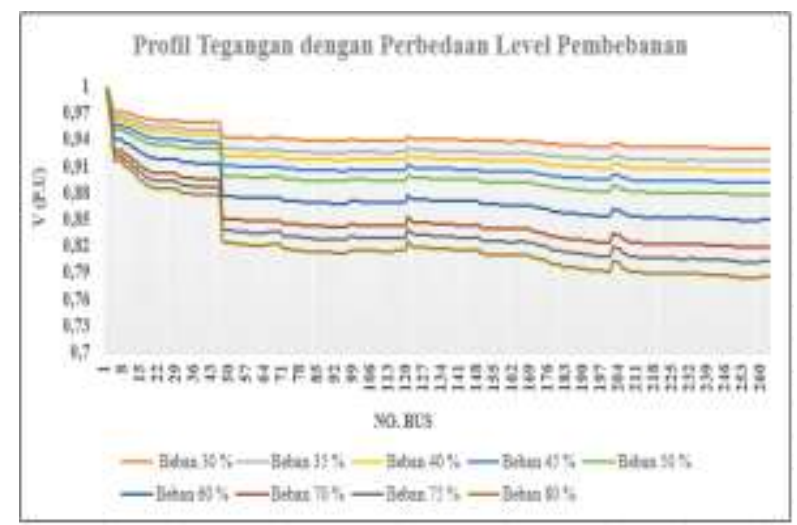

Gbr 7. Perbandingan Profil Tegangan Setelah Penempatan Bank Kapasitor

Tabel 5. Perbandingan Tegangan Terendah Sebelum dan Sesudah Optimasi Untuk Setiap Level Pembebanan

\begin{tabular}{|c|c|c|c|c|c|c|c|}
\hline \multirow{2}{*}{ Beten } & \multicolumn{3}{|c|}{ Setelm 0ptims } & \multicolumn{3}{|c|}{ Setelat 0pinasi } & \multirow{2}{*}{ Peninglema (10) } \\
\hline & $\operatorname{Vun}(\mathrm{p}$. & $\mathrm{IA}(\mathrm{beq})$ & $\mathrm{Sa} B \mathrm{Bz}$ & Thin (p.1) & $\mathrm{TA}(\mathrm{deg})$ & Sa. B B & \\
\hline 36 & 0,945 & -0.3655 & 59 & 094116 & 41850 & 159 & 078 \\
\hline 156 & 095156 & $-0,4679$ & 159 & 0,0088 & $-1,40299$ & 159 & 1,198 \\
\hline $40 \%$ & 0,5638 & $0.527 \mathrm{H}$ & 59 & 0991700 & .137393 & 159 & 1,079 \\
\hline Wh & 0.612 & $0.6 \mathrm{RHY}$ & 259 & 091686 & .236425 & 159 & 2,9 \\
\hline $5 \%$ & 0,776 &  & 59 & 090013 & .27756 & 159 & $2+45$ \\
\hline $\mathrm{NO}$ & OPHEs? & 0.4497 & 259 & 0,8133 & $-3,05102$ & 159 & 2800 \\
\hline$W$ & 0,1156 & $-1,642$ & 159 & 0,8060 & 4,10274) & 159 & 315 \\
\hline 76 & 0.01016 & $-1,1161$ & 269 & 0,80200 & $-3,07365$ & 259 & 299 \\
\hline 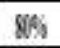 & $0.74+32$ & -1.21774 & 39 & 0.84872 & .527681 & 159 & $6:[A\}$ \\
\hline
\end{tabular}

Hasil optimasi menunjukkan bahwa secara keseluruhan tegangan pada semua bus pada masing-masing pembebanan dapat ditingkatkan dengan adanya penambahan kapasitas daya reaktif yang diinjeksikan oleh bank kapasitor pada lokasi dan kapasitas yang optimum, dimana pada tabel 5 diperlihatkan peningkatan tegangan terendah pada bus 259 saat sebelum dan sesudah penempatan bank kapasitor.

Pada pengujian ini digunakan switched capacitor bank dengan pertimbangan bahwa besar daya reaktif kompensasi dapat diubah sesuai dengan perubahan beban dengan mengatur posisi tap. Jumlah kandidat bus untuk penempatan kapasitor ditetapkan sebanyak 5 bus dan hasil pengujian menggunakan metode LSF diperoleh bus-bus sebagai kandidat adalah masing-masing pada bus 4, bus 71, bus 96, bus 191 dan bus 251 . Kapasitas optimum switched capacitor bank ditunjukkan pada tabel 6 dan tabel 7 di bawah ini.

Tabel 6. Kapasitas Optimum Switched Capacitor Bank Pada Penyulang Pakis 263 Bus

\begin{tabular}{|c|c|c|c|c|c|c|c|c|c|}
\hline \multicolumn{10}{|c|}{ Tap Kontrol Svitched Capacitor Bank (kVAR) Untuk } \\
\hline \multicolumn{1}{|c|}{ Level Pembebanan Berbeda } \\
\hline No. Bus & $\mathbf{3 0 \%}$ & $\mathbf{3 5 \%}$ & $\mathbf{4 0 \%}$ & $\mathbf{4 5 \%}$ & $\mathbf{5 0 \%}$ & $\mathbf{6 0 \%}$ & $\mathbf{7 0 \%}$ & $\mathbf{7 5 \%}$ & $\mathbf{8 0 \%}$ \\
\hline $\mathbf{4}$ & 50 & 50 & 50 & 50 & 100 & 50 & 50 & 100 & 200 \\
\hline $\mathbf{7 1}$ & 50 & 150 & 50 & 350 & 150 & 400 & 50 & 150 & 750 \\
\hline $\mathbf{9 6}$ & 50 & 100 & 150 & 100 & 100 & 150 & 300 & 100 & 300 \\
\hline $\mathbf{1 9 1}$ & 50 & 100 & 100 & 100 & 300 & 150 & 100 & 500 & 500 \\
\hline $\mathbf{2 5 1}$ & 100 & 50 & 50 & 150 & 200 & 200 & 500 & 100 & 250 \\
\hline Total & $\mathbf{3 0 0}$ & $\mathbf{4 5 0}$ & $\mathbf{4 0 0}$ & $\mathbf{7 5 0}$ & $\mathbf{8 5 0}$ & $\mathbf{9 5 0}$ & $\mathbf{1 0 0 0}$ & $\mathbf{9 5 0}$ & $\mathbf{2 0 0 0}$ \\
\hline
\end{tabular}

Tabel 7. Nilai Kapasitas Optimum Penempatan Capacitor Bank Pada Penyulang Pakis 263 Bus

\begin{tabular}{|c|c|c|}
\hline \multicolumn{3}{|c|}{ Base Unit Capacitor Bank $=\mathbf{5 0}$ KVAR } \\
\hline No.Bus & Kapasitas Cap.Bank (KVAR) & Jumlah Tap \\
\hline 4 & 200 & 4 \\
\hline 71 & $\mathbf{7 5 0}$ & 15 \\
\hline 96 & 300 & 6 \\
\hline 191 & 500 & 10 \\
\hline 251 & 500 & 10 \\
\hline Total & $\mathbf{2 2 5 0}$ & $\mathbf{4 5}$ \\
\hline
\end{tabular}

Injeksi daya reaktif oleh penempatan capacitor bank pada bus-bus kandidat mengakibatkan penurunan injeksi arus oleh slack bus sehingga rugi-rugi daya pada sistem distribusi mengalami penurunan. Total penurunan rugi-rugi daya aktif dan rugi-rugi daya reaktif pada Penyulang Pakis diperlihatkan pada gambar 8 dan 9 .

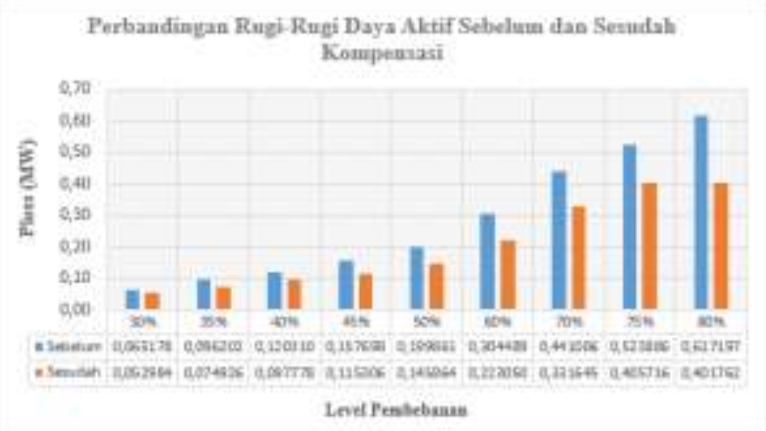

Gbr. 8. Perbandingan daya aktif total dengan kondisi pembebanan berbeda sebelum dan sesudah penempatan bank kapasitor. 


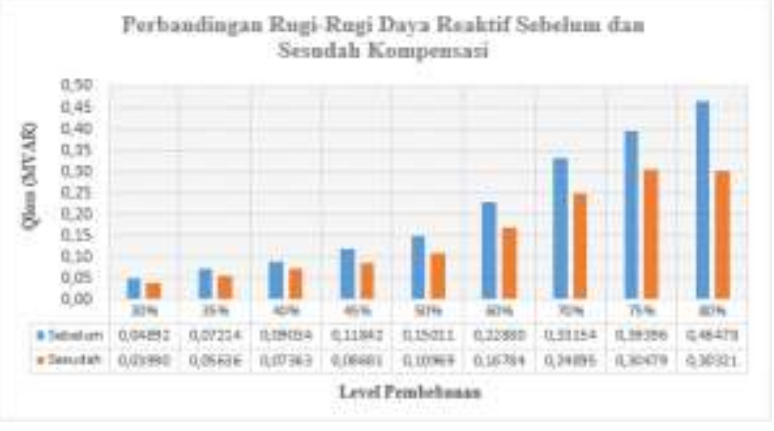

Gbr 9. Perbandingan rugi-rugi daya reaktif total dengan kondisi pembebanan berbeda sebelum dan sesudah penempatan bank kapasitor.

Hasil optimasi menunjukkan rata-rata penurunan rugi-rugi daya aktif sebesar $24,718 \%$, dimana penurunan rugi-rugi daya aktif terbesar terjadi ketika kondisi pembebanan $80 \%$ yaitu sebesar $34,905 \%$ dari nilai rugi-rugi daya aktif sebelum optimasi sebesar 0,617197 MW menjadi 0,401762 MW setelah dilakukan optimasi. Demikian pula dengan rugi-rugi daya reaktif yang mengalami penurunan rata-rata sebesar $24,597 \%$ dari kondisi sebelum optimasi. Penurunan terbesar terjadi pada kondisi beban $80 \%$ yaitu sebesar $34,762 \%$ dari nilai 0,46478 MVAR menjadi 0,30321 MVAR.

Berkurangnya nilai rugi-rugi daya ini memberikan pengaruh positif terhadap penghematan biaya operasi tahunan yang diperlihatkan pada tabel 8 .

Tabel 8. Penghematan Biaya Operasi Tahunan Setelah Penempatan Bank Kapasitor

\begin{tabular}{|c|c|c|c|c|}
\hline $\begin{array}{c}\text { Leval } \\
\text { Beban } \\
\text { (95) }\end{array}$ & $\begin{array}{l}\text { Biaya Ragi: } \\
\text { Rugi Energi } \\
\text { Sebelum } \\
\text { Optimasi (S) }\end{array}$ & $\begin{array}{c}\text { Biaya Kugi-Rugi } \\
\text { Eaergi Sestudah } \\
\text { Optimasi (5) }\end{array}$ & $\begin{array}{c}\text { Biaya } \\
\text { Capocitar } \\
\text { Bank (\$) }\end{array}$ & $\begin{array}{c}\text { Penghemiatan } \\
\text { Miaya Tahunaan (9) }\end{array}$ \\
\hline $30 \%$ & 4282,201 & 3481,060 & 900 & $-98,804$ \\
\hline $35 \%$ & 6320,438 & 4922,611 & 1350 & 47,826 \\
\hline $40 \% 5$ & 5209.58 & 4282.659 & 1200 & $-213,078$ \\
\hline $45 \%$ & 17267938 & 12626,046 & 2250 & 2391,89 \\
\hline $50 \%$ & 13130,837 & 9583,274 & 2550 & 997,562 \\
\hline $60 \%$ & 13336,635 & 9769,600 & 2850 & 717,025 \\
\hline $70 \%$ & 19316,065 & 14526,046 & 3000 & 1790,018 \\
\hline $75 \%$ & 11473,094 & 8885,156 & 2850 & $-262,092$ \\
\hline $900 \%$ & 40549,82 & 26395.795 & 6000 & 8154,024 \\
\hline Total & $130,946,605$ & 94.472 .292 & 22.950 & $13,524,316$ \\
\hline
\end{tabular}

Tabel 8 menunjukkan menunjukkan perbandingan biaya operasi tahunan saat sebelum dan sesudah pemasangan bank kapasitor pada Penyulang Pakis, dimana total biaya rugi-rugi energi dalam jangka waktu setahun sebelum adanya pemasangan bank kapasitor adalah sebesar \$130.946,608, saat setelah dilakukan optimasi dengan pemasangan bank kapasitor di 5 lokasi yang paling optimum, maka didapatkan penurunan total biaya rugi-rugi energi selama setahun yaitu menjadi hanya sebesar $\$ 94.472,292$, dengan total biaya pemasangan bank kapasitor sebesar \$22.950. Hasil ini menunjukkan bahwa dengan adanya pemasangan bank kapasitor, maka akan diperoleh penghematan biaya sebesar $\$ 13.524,316$ dalam waktu setahun.

\section{PENUTUP}

Kombinasi metode Loss Sensitivity Factor dan Particle Swarm Optimization dapat menyelesaikan masalah optimasi penempatan dan kapasitas fixed atau switched capacitor bank untuk mereduksi rugi-rugi daya yang optimal pada kedua kasus uji sistem distribusi, baik kasus uji IEEE 10 bus dan penyulang Pakis di Gardu Induk Menggala.

\section{REFERENSI}

[1] B.M. Weedy, Electric Power System (Fifth Edition), United Kingdom: John-Wiley and Sons, 2012.

[2] T. Gonen, Electric Power Distribution System Engineering, United States: McGraw-Hill Inc., 1986.

[3] L. Hakim, U. Murdika, H. Gusmedi, S. Zaini, A Study on Reactive Power Allocation for Electrical Power Distribution System with Low Voltage Profile, International Conference on Science, Technology and Interdisciplinary Research, Bandar Lampung, 2015.

[4] S. Kaur, G.B. Kumbhar and J. Sharma, Performance of Mixed Integer Non-Linear Progamming and Improve Harmony Search for Optimal Capacitor Placement of DG units, IEEE Conference and Exposition on PES General Meeting. National Harbor, MD. USA. 2014.

[5] R. de Sa Fereira, A Mixed-Integer Linear Progamming Approach to the AC optimal Reactive Power Flow in Distribution System, Brasil, 2013. 
[6] V. Ajjarapu and Z. Albanna, Application of Genetic Algorithm to Optimal Capacitor Placement, IEEE Proceedings of the First International Forum on Applications on Neural Networks to Power Systems. Seattle, WA. USA, 1991.

[7] T. Ghose, S.K. Goswani and S.K. Basu, Energy Loss Reduction in Distribution System by Capacitor Placement through Combined GA-SA Technique, IEEE Region 10 International Conference on Global Connectivity in Energy, Computer, Communication, and Control, New Delhi. vol. 2. pp. 502-505, 1998.

[8] S. M. Kannan, A. Rathina, G. Monica and S. M. R. Slochanal, Fuzzy Logic Based Optimal Capacitor Placement on Radial Distribution Feeders", Joint International Conference on Power System Technology and IEEE Power India Conference, pp.1-6. New Delhi, 2008.

[9] Y.C. Huang, H.T. Yang, and C.L. Huang, Solving the Capacitor Placement Problem a Radial Distribution System Using Tabu Search Method, IEEE Transactions on
Power Systems, vol.1, no.4, pp. 1868-1873, November, 1996.

[10] K. Prakash and M. Sydulu, Particle Swarm Optimization based Capacitor Placement on Radial Distribution Systems, IEEE Conference on Power Engineering Society General Meeting, Tampa, Florida, United States, 2007.

[11] R. Eberhart and J. Kennedy, Particle Swarm Optimization, Proceedings of the IEEE International Conference on Neural Networks, IEEE Service Center Piscataway, 1995.

[12] C.T. Su and C.C. Tsai, A New Fuzzy Reasoning Aprroach to Optimum Allocation For Primary Distribution Systems, IEEE International Conference on Industrial Technology, Taiwan, 1996.

[13] N. Gnanasekaran, S. Chandramohan, Maximum Cost Saving Approach for Optimal Capacitor Placement in Radial Distribution System Using Modified ABC Algorithm, International Journal on Electrical Engineering and Informatics, vol.8, no.4, India, 2015. 